\title{
Acceptance of Information and Communication Technology for Vocational High School Management
}

\author{
Daryanto ${ }^{1}$ and Siswantari ${ }^{2}$ \\ ${ }^{1}$ Electrical Engineering Education Study Program, Faculty of Engineering, Jakarta State \\ University, Jakarta, Indonesia \\ ${ }^{2}$ Center for Education and Culture Policy Research, Board of Research and Development, \\ Ministry of Education and Culture, Jakarta, Indonesia
}

\section{Abstract}

The successful use of Information and Communication Technology (ICT) for school management is basically influenced by organizational and technological factors. Organizational factors are management's ability to use ICTs to support school management, while technological factors relate to the ICT itself and the user behavior in utilizing ICT is used to support their performance. The acceptance of ICT is the

Corresponding Author:

Daryanto

daryanto@unj.ac.id

Received: 11 January 2019

Accepted: 14 February 2019

Published: 25 March 2019

Publishing services provided by Knowledge E

(c) Daryanto and Siswantari. This article is distributed under the terms of the Creative Commons Attribution License, which permits unrestricted use and redistribution provided that the original author and source are credited.

Selection and Peer-review under the responsibility of the 3rd ICTVET 2018 Conference Committee. behavior of users in utilizing ICT that is indicated by the perceived usefulness of ICT, perceived ease in using ICT, attitude toward behavior using ICT, and the actual use of ICT by users. In general, this study aims to determine the effect of school culture on various aspects of ICT acceptance for the management of Vocational Schools in the Jakarta Region. The method used in this study is a causal survey with a randomly selected sample of 245. Path analysis with the partial least square (PLS) approach was used to analyze the research data. The results showed that the school culture had a direct influence on the perceived usefulness of ICT, and perceived ease in using ICT with path coefficients of 0.282 and 0.169 ; perceived ease in using ICT directly affects the perceived usefulness of ICT and attitude toward behavior using ICT with path coefficients of 0.452 and 0.504; the perceived usefulness of ICT has a direct effect on attitude toward behavior using ICT with a path coefficient of 0.280 ; attitude toward behavior using ICT directly influences the actual use of ICT by users with path coefficient 0.587; and the actual use of ICT by users directly influences the effectiveness of school management with a path coefficient of 0.526 . The conclusion in this study is that school culture has a positive and significant influence on the acceptance of ICT for school management.

Keywords: school culture, acceptance of ICT, school management, vocational high school

\section{Introduction}

Revitalization of Vocational High Schools in Indonesia basically aims to improve the G OPEN ACCESS 
Vocational High Schools must emphasize high-order thinking skills (HOTs) and literacy in the ICT field that are strengthened by character education. For this reason, better management of school resources is needed. School resources include infrastructure, teachers and administrative staff, school culture and school environment, and others. Better school management is the key to success in the implementation of Vocational High Schools. School management is the process of utilizing all potential school resources in carrying out rational activities through planning, organizing, and evaluating to achieve efficient and effective goals. The role of technology, especially ICT, is very necessary to support the achievement of efficient and effective school management. However, ICT as a tool will be useful if it is used and accepted by the user to support their activities. According to Roger [1], the process of technology acceptance is influenced by the social system in which the diffusion process occurs. Communication network structures such as values, school culture, leadership, and others can affect the acceptance of ICTs in Vocational High Schools. Certain patterns regarding the habits of teachers and administrative staff will appear in school organizations such as Vocational High Schools. This is due to the fact that schools have their own patterns and positions in the culture that occur in society. Each school will bring its own culture, so that in the process of improving the quality of the school an understanding of school culture is needed by teachers, employees, students, and other stakeholders. Dynamic school culture is a shared property that is formed from the history of the school and real products as a result of the interaction of various forces that are incorporated into the school. The ICT diffusion process is a long process that requires a spirit of togetherness, openness, self-discipline, responsibility, and mutual respect which will then become the basis for teachers, students, employees and other stakeholders in adopting or accepting ICTs to support school management. Understanding of school culture can create a conducive environment for applying new technology into school management. The use of technology to support school management generally only pays attention to technological factors, not yet paying attention to other factors, especially those related to social factors users who will utilize these technologies. Through surveys of teachers and employees in utilizing ICT for school management, it is expected that they can reveal what aspects influence ICT acceptance that can be used as a basis for policy making related to the application of ICT for school management in Vocational High Schools in the Jakarta Region.

\section{Methods and Equipment}




\subsection{Methods}

The method used in this research is a causal survey with a path analysis approach. The research was conducted in 20 Vocational High Schools in the Jakarta area with a sample of 245 people consisting of 100 employees and 145 teachers taken by proportional random sampling. While the research data were analyzed using path analysis with the Partial Least Square (PLS) approach which is an alternative to structural equation modeling. The initial model of influence between variables is to evaluate the structural model which includes the coefficient of determination $\left(R^{2}\right)$, predictive relevance $\left(Q^{2}\right)$, effect size $\left(f^{2}\right)$ and estimate for path coefficients. The structural model or inner model is a model that describes the relationship between latent variables. Structural models that meet the criteria are then determined to be the final model. Effect size is used to know the goodness of the model, whereas prediction relevance or known as Stone-Geisser's is used to know predictability capabilities and calculations are done with blindfolding procedures. The value of $f^{2}$ and $Q^{2}$ used is 0.15 , which is a latent variable predictor that has a moderate to large influence. The determination coefficient of endogenous construct according to Chin used is 0.33 [2]. Path coefficients must be positive and significant, negative path coefficients are not used so that the relationship of latent constructs with negative path coefficients is omitted.

\subsection{Structural model design}

The design of a structural model that shows the relationship between latent variables of the study as shown in Figure 1 below:

The ICT acceptance model is modified from the technology acceptance model developed by Davis [3]. The ICT acceptance variable consists of aspects of user motivation in using ICT and the actual use of ICT by users (ATU ICT). User motivation consists of: (1) perceived usefulness of ICT, (2) perceived ease in using ICT (PEU ICT), (3) and attitude towards behavior using ICT (BIU ICT). The four aspects of the ICT acceptance variable are assumed to be influenced by school culture. School culture also influences the effectiveness of school management (SME). Path coefficients that are negative or influence between variables that are not significant, the path that connects between these variables is omitted. The final structural model is a structural model consisting of positive path coefficients and the influence between variables is significant. 


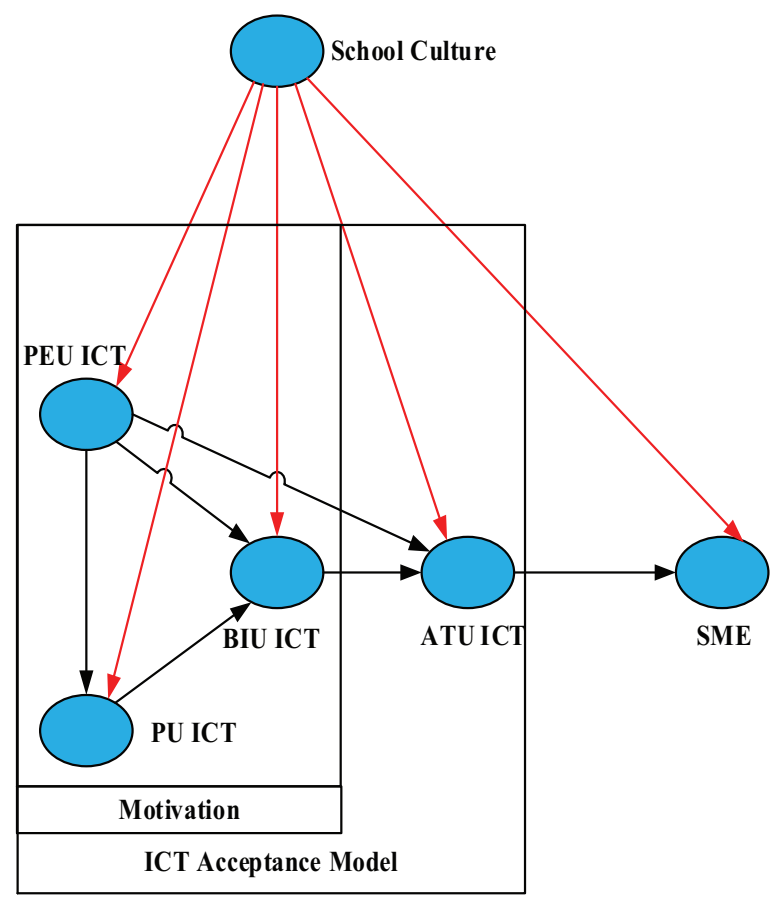

Figure 1: Model of the Influence of School Culture with ICT Acceptance.

\section{Results}

The path coefficients of the influence of school culture on aspects of ICT acceptance in Vocational High Schools in the Jakarta Region and school management effectiveness variables calculated using the SmartPLS program are shown in Figure 1 below:

While the path coefficients, standard deviations, $T$-statistics and $P$-values are shown in the following Table 1:

TABLE 1: Path Coefficients, Mean, STDEV, $T$-Values, dan $P$-Values.

ATU ICT $\rightarrow$ SME
BIU ICT $\rightarrow$ ATU ICT
PEU ICT $\rightarrow$ BIU ICT
PEU ICT $\rightarrow$ PU ICT
PU ICT $\rightarrow$ BIU ICT
School Culture $\rightarrow$ PEU ICT
School Culture $\rightarrow$ PU ICT
PEU ICT $\rightarrow$ ATU ICT
School Culture $\rightarrow$ ATU ICT
School Culture $\rightarrow$ BIU ICT
School Culture $\rightarrow$ SME

\begin{tabular}{|c|c|c|c|}
$\begin{array}{c}\text { Original } \\
\text { Sample (O) }\end{array}$ & $\begin{array}{c}\text { Sample } \\
\text { Mean (M) }\end{array}$ & $\begin{array}{c}\text { Standard } \\
\text { Deviation } \\
\text { (STDEV) }\end{array}$ & $\begin{array}{c}\text { T-Statistics } \\
\text { (IO/STDEVI) }\end{array}$ \\
\hline 0.576 & 0.579 & 0.068 & 8.512 \\
\hline 0.680 & 0.695 & 0.137 & 4.957 \\
\hline 0.690 & 0.692 & 0.084 & 8.194 \\
\hline 0.541 & 0.542 & 0.054 & 9.952 \\
\hline 0.190 & 0.186 & 0.087 & 2.182 \\
\hline 0.212 & 0.222 & 0.087 & 2.432 \\
\hline 0.304 & 0.303 & 0.070 & 4.364 \\
\hline $\mathbf{0 . 2 1 3}$ & $\mathbf{0 . 2 0 1}$ & $\mathbf{0 . 1 3 9}$ & $\mathbf{1 . 5 2 7}$ \\
\hline $\mathbf{0 . 0 8 8}$ & $\mathbf{0 . 0 8 6}$ & $\mathbf{0 . 0 4 8}$ & $\mathbf{1 . 8 3 8}$ \\
\hline $\mathbf{0 . 0 1 2}$ & $\mathbf{0 . 0 1 7}$ & $\mathbf{0 . 0 6 1}$ & $\mathbf{0 . 1 9 5}$ \\
\hline $\mathbf{0 . 0 0 4}$ & $\mathbf{0 . 0 0 0}$ & $\mathbf{0 . 0 7 8}$ & $\mathbf{0 . 0 5 5}$ \\
\hline
\end{tabular}

P-Values

0.000

0.000

0.000

0.000

0.030

0.015

0.000

0.127

0.067

0.845

0.956 


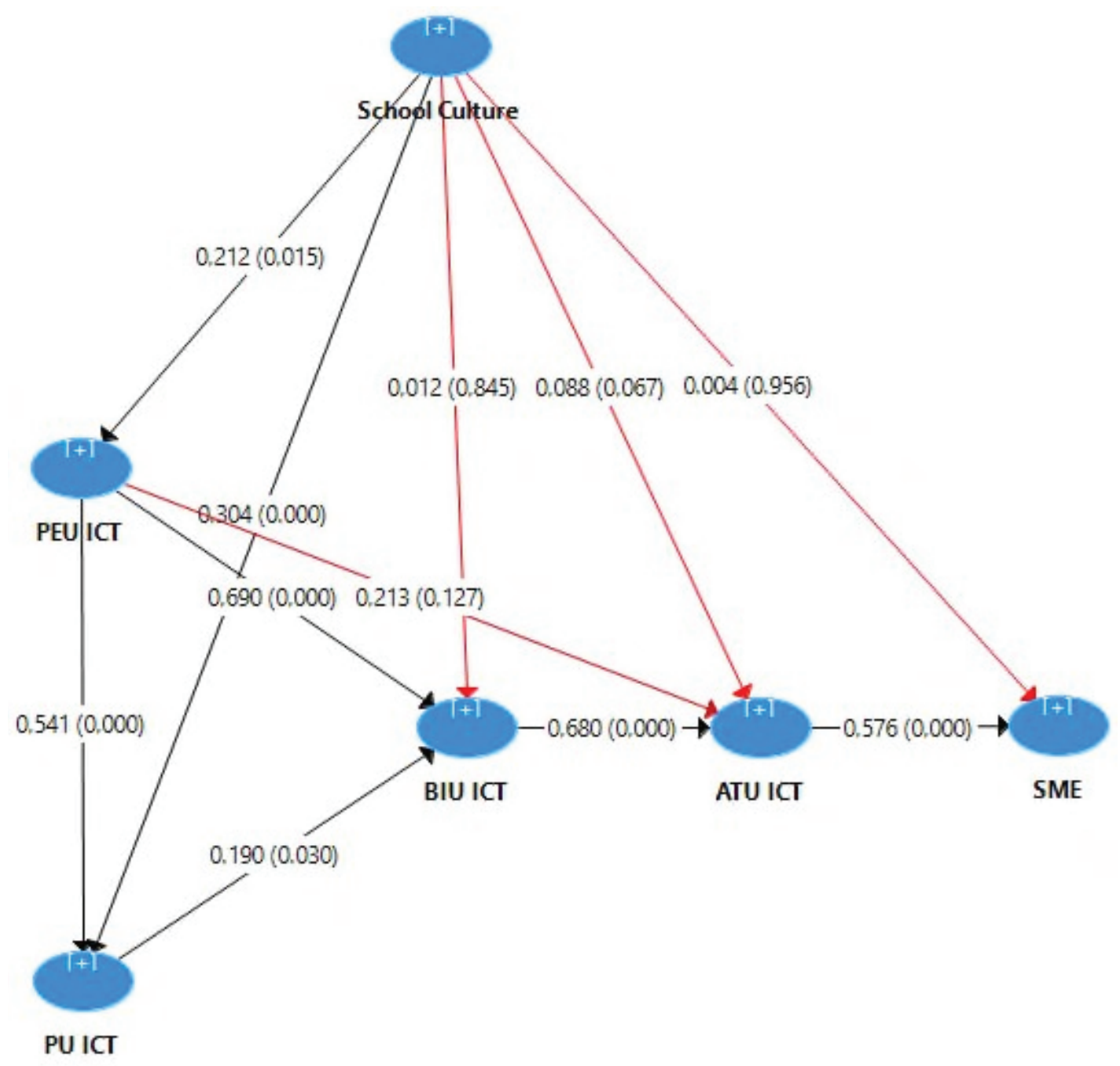

Figure 2: Path Coefficients between Research Variables.

The influence between variables is not significant if the $T$-statistic $<1.96$ and $P$-values $>0.050$. Based on Table 1, the insignificant path coefficients are found in the influence of perceived ease in using ICT on the actual use of ICT by users, the influence of school culture on the actual use of ICT by users, the influence of school culture on attitudes toward behavior using ICT, and the influence of school culture on the effectiveness of school management. The path that does not have a significant effect is then removed and a new structural model is formed and then the path coefficient is recalculated. The final structural model drawing with its path coefficient is shown in the following Figure 3:

While the path coefficient values, standard deviations, $T$-statistics and $P$-values are shown in the following Table 2:

Based on the final structural model and Table 2 above, the results of this study are: 


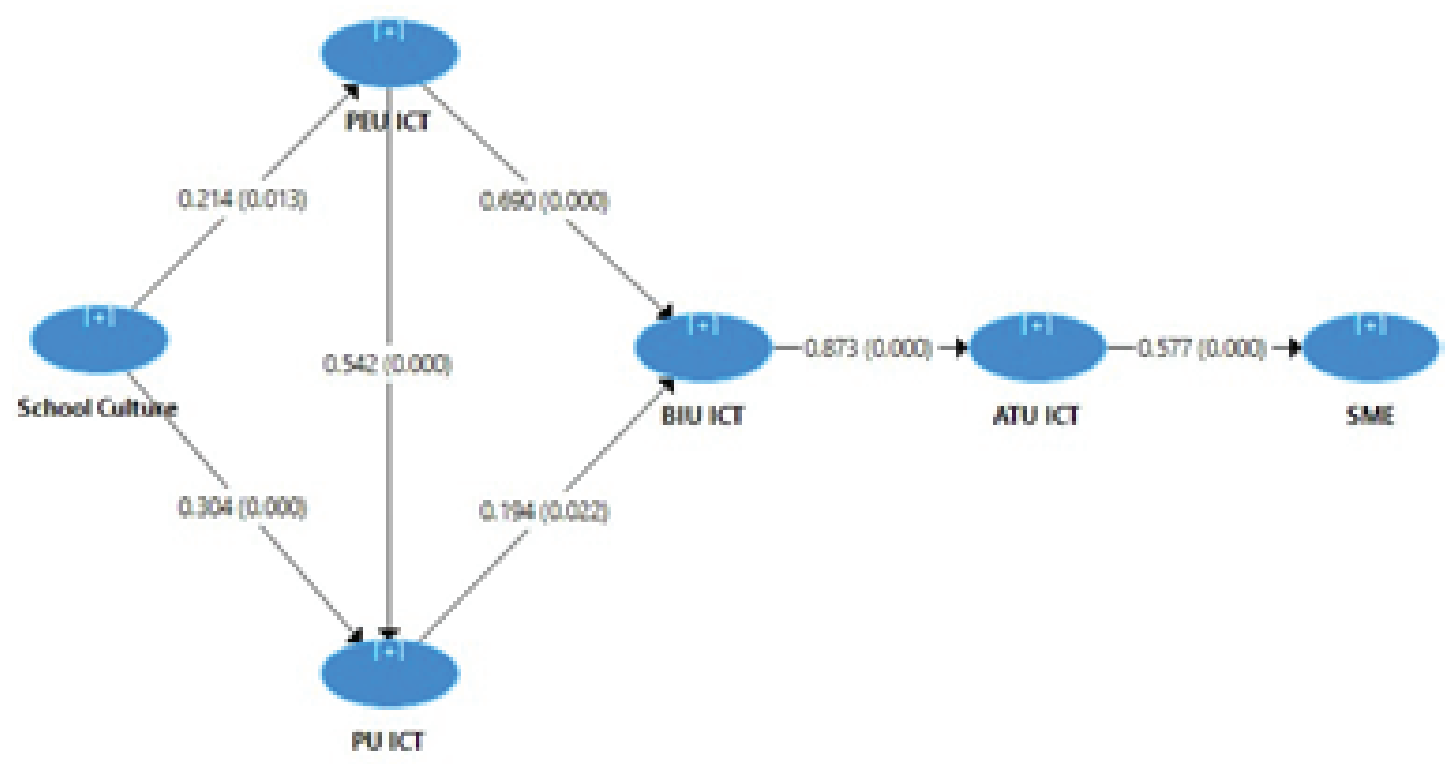

Figure 3: Final Structural Model with Path Coefficient and Probability Value.

TABLE 2: Path Coefficients, Mean, STDEV, $T$-Values, and P-Values for Final Structural Models.

\begin{tabular}{|l|c|c|c|c|c|} 
& $\begin{array}{c}\text { Original } \\
\text { Sample } \\
(\mathbf{O})\end{array}$ & $\begin{array}{c}\text { Sample } \\
\text { Mean } \\
\text { (M) }\end{array}$ & $\begin{array}{c}\text { Standard } \\
\text { Deviation } \\
\text { (STDEV) }\end{array}$ & $\begin{array}{c}\text { T-Statistics } \\
(\text { (IO/STDEVI) }\end{array}$ & P-Values \\
\hline ATU ICT $\rightarrow$ SME & 0.577 & 0.575 & 0.058 & 10.027 & 0.000 \\
\hline BIU ICT $\rightarrow$ ATU ICT & 0.873 & 0.876 & 0.032 & 27.128 & 0.000 \\
\hline PEU ICT $\rightarrow$ BIU ICT & 0.690 & 0.689 & 0.083 & 8.347 & 0.000 \\
\hline PEU ICT $\rightarrow$ PU ICT & 0.542 & 0.543 & 0.056 & 9.730 & 0.000 \\
\hline PU ICT $\rightarrow$ BIU ICT & 0.194 & 0.193 & 0.085 & 2.292 & 0.022 \\
\hline School Culture $\rightarrow$ PEU ICT & 0.214 & 0.225 & 0.086 & 2.500 & 0.013 \\
\hline School Culture $\rightarrow$ PU ICT & 0.304 & 0.307 & 0.071 & 4.264 & 0.000 \\
\hline
\end{tabular}

1. School culture has a direct effect on the perceived usefulness of ICT with a path coefficient of 0.304 .

2. School culture has a direct effect on the perceived ease in using ICT with a path coefficient of 0.214 .

3. Perceived usefulness of ICT has a direct effect on attitude towards behavior using ICT with a path coefficient of 0.194 .

4. Perceived ease in using ICT has a direct effect on the perceived usefulness of ICT with a path coefficient of 0.542 .

5. Perceived ease in using ICT has a direct effect on attitude towards behavior using ICT with a path coefficient of 0.690 . 
6. Attitude towards behavior using ICT directly influences the actual use of ICT with a path coefficient of 0.873 .

7. Actual use of ICT by users has a direct effect on the effectiveness of school management with a path coefficient of 0.577 .

\section{Discussion}

Each school generally has a different school culture. The uniqueness is a personality that describes how the school carries out its role and duties as an educational institution that will educate students to have the desired competencies. Understanding of school culture can provide an overview of everyday realities and hidden structures that occur in the school. This understanding can encourage efforts to improve school quality through meaningful relationships and accepting changes that occur. The rapid development of ICTs will affect organizational change and the people involved in it, so that integrating ICT into organizations must involve various aspects such as ICT infrastructure, school leadership, teachers, students, school culture, school programs, and so on. The application of ICT for the management of Vocational High Schools must be preceded by studying the socio-cultural aspects of the school culture. Davis [3] warns that a lack of understanding of cultural dynamics can ultimately lead to negative results. Therefore teachers, employees, students, and other stakeholders must first understand the culture prevailing in their schools before using ICT, this is intended to ensure that there are factors that can influence the use of ICT.

The process of acceptance of ICT in Vocational High Schools starts with exploring, researching, and deciding to use ICT, then introducing the ICT to teachers, employees, students, parents, and other stakeholders. If ICT is accepted for use in school management, the next step is to use the ICT. The influence of school culture on ICT acceptance is based on self-awareness with a strong commitment to getting used to using ICTs in carrying out their activities. The perceived ease in using ICTs is the rate at which a person believes that using ICT does not require heavy effort. The experience of someone in using ICT and the assessment of ICT reputation by the user is a consideration in improving the perception of the ease of using the ICT. The role of culture becomes important because through culture a person can get used to treating ICT as a tool that can facilitate work completion.

Luthans [4] states that the acceptance of ICT individually and collectively can improve organizational performance. Someone will still use ICT if the system is useful, whether the system is easy to use or not easy to use. Systems that are difficult to use will 
still be used if they feel that the system is still useful [5]. While perceived usefulness according to Warshaw et al. is the subjective probability that prospective users who will use the appropriate application system will improve their work performance [6]. Attitudes towards behavior in using ICT will encourage someone to truly use ICT. A person's behavior in using ICT begins with a perception of the usefulness and ease of using ICT, which in turn a person will have the attitude to use and continue to use ICT to support his work. According to Davis, the attitude of users towards the system is the main determinant of whether the user will actually use or reject the system [7]. The attitude of users in turn is influenced by two main beliefs, namely perceived usefulness and perceived ease in using ICT with perceived ease in using ICT having a direct influence on perceived benefits.

Vocational High Schools that have effective school management are schools that are managed well, accountably, transparently, and are able to utilize resources optimally so that they can achieve school goals effectively and efficiently. School effectiveness basically shows the degree of conformity between the results achieved and the expected ones. According to Ewell and Lisensky that effectiveness is oriented towards results that emphasize the actual development of organizational procedures by administrators (management process), and organizational climate that pays attention to internal processes and interpersonal relations (organizational climate) [8]. Effectiveness also shows the harmony of relationships within and outside the organization's environment (environmental adaptation). The use of technology such as ICT in school management will ensure the efficiency of school management and organizations. School management requires accuracy in planning, directing, controlling and controlling resources including finance, school document storage, information flow, and others. Without using technology assistance such as ICT, it will take a long time and a lot of labor, which in turn can require a lot of money.

\section{Conclusion}

1. The aspect that plays a role in the acceptance of ICT for the management of Vocational High Schools in the Jakarta Region is the perceived usefulness of ICT and perceived ease in using ICT, the attitude towards behavior using ICT, and the actual use of ICT by users for school management.

2. School culture directly influences perceived usefulness of ICT and perceived ease in using ICT and indirect effects on attitude towards behavior using ICT. The actual use of ICT by users directly influences the effectiveness of school management. 
3. The actual use of ICT by users has a direct effect on the effectiveness of Vocational High School management in the Jakarta Region.

\section{Funding}

This research was funded by the BLU POK funds, Faculty of Engineering, Jakarta State University based on the Decree of Committing Officer of the Faculty of Engineering, Jakarta State University, Number: 461.a/SP/2018, dated: May 23, 2018.

\section{Acknowledgement}

In this study, the authors would like to thank the Dean of the Faculty of Engineering, Jakarta State University and its staff, the Study Program Coordinators, Reviewers, and all parties who directly or indirectly completed the research and writing of this article.

\section{References}

[1] Everett M. Rogers. (1983). Diffusion of Innovations. New York: Macmillan Publishing Co., Inc.

[2] Chin W.W. (2003): "PLS-Graph User's Guide”, C.T. Bauer College of Business, University of Houston, USA

[3] Davis F. D. (1986). User Acceptance of information technology: System characteristics, user perceptions, and behavioral impacts, International Journal of Man Machine Studies, 38, 475-487.

[4] Luthans, F., \& Avolio, B. J. (2003). Authentic leadership: A positive development approach. In K. S. Cameron, J. E. Dutton, \& R. E. Quinn (Eds.), Positive organizational scholarship: Foundations of a new discipline. HIm. 241-261.

[5] Igbaria, M., N. Zinatelli, P. Cragg, dan A. L. M. Cavaye, (1997), "Personal Computing Acceptance Factors in Small Firms: A Structural Equation Model”, MIS Quarterly, 21/3: 279-305.

[6] Davis, F. D., Bagozzi, R. P., and Warshaw, P. R. (1989). User Acceptance of Computer Technology: A Comparison of Two Theoretical Models, Management Science, 35 (8), 982-1003

[7] Davis, F. D., \& Venkatesh, V.(1996). A Critical Assessment Of Potential Measurement Biases In The Technology Acceptance Model: Three Experiments, International Journal Of Human- Computer Studies, 45, 19-45 
[8] Ewell, PT and Lisensky, RP (1998)Assessing Institutional Effectiveness: Redirecting the Self-study Process, Washington, DC: Consortium for the Advancement of Private Higher Education. 